\title{
Article \\ Multifunctionality of Rapeseed Meal Protein Isolates Prepared by Sequential Isoelectric Precipitation
}

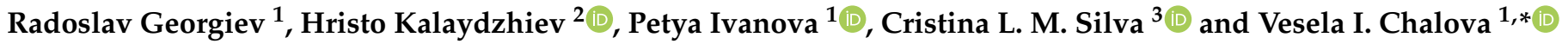 \\ 1 Department of Biochemistry and Molecular Biology, University of Food Technologies, 26 Maritsa Blvd, \\ 4002 Plovdiv, Bulgaria; racho95@abv.bg (R.G.); petia_ivanova_georgieva@abv.bg (P.I.) \\ 2 Department of Analytical Chemistry and Physicochemistry, University of Food Technologies, 26 Maritsa Blvd, \\ 4002 Plovdiv, Bulgaria; hristo.kalaydzhiev@yahoo.com \\ 3 CBQF-Centro de Biotecnologia e Química Fina-Laboratório Associado, Escola Superior de Biotecnologia, \\ Universidade Católica Portuguesa, Rua Diogo Botelho 1327, 4169-005 Porto, Portugal; clsilva@porto.ucp.pt \\ * Correspondence: veselachalova@gmail.com; Tel.: +359-32-603-855
}

Citation: Georgiev, R.; Kalaydzhiev, H.; Ivanova, P.; Silva, C.L.M.; Chalova, V.I. Multifunctionality of Rapeseed Meal Protein Isolates Prepared by Sequential Isoelectric Precipitation. Foods 2022, 11, 541. https://doi.org/10.3390/ foods11040541

Academic Editor: Maria Hayes

Received: 30 December 2021

Accepted: 5 February 2022

Published: 14 February 2022

Publisher's Note: MDPI stays neutral with regard to jurisdictional claims in published maps and institutional affiliations.

Copyright: (C) 2022 by the authors. Licensee MDPI, Basel, Switzerland. This article is an open access article distributed under the terms and conditions of the Creative Commons Attribution (CC BY) license (https:// creativecommons.org/licenses/by/ $4.0 /)$.

\begin{abstract}
Rapeseed meal is a by-product of the oil-producing industry with a currently underestimated application. Two protein isolates, $\mathrm{PI}_{2.5-8.5}$ or $\mathrm{PI}_{10.5-2.5}$, were obtained from industrial rapeseed meal after treatment with an aqueous ethanol solution. The alkaline-extracted proteins were sequentially precipitated by two different modes, from $\mathrm{pH} 10.5$ to 2.5 , and vice versa, from 2.5 to 8.5 , with a step of $1 \mathrm{pH}$ unit. The preparation approach influenced both the functional and antioxidant properties of the isolates. The $\mathrm{PI}_{10.5-2.5}$ exhibited higher water and oil absorption capacities than $\mathrm{PI}_{2.5-8.5}$, reaching $2.68 \mathrm{~g} \mathrm{H}_{2} \mathrm{O} / \mathrm{g}$ sample and $2.36 \mathrm{~g}$ oil/g sample, respectively. The emulsion stability of the $\mathrm{PI}_{2.5-8.5}$, evaluated after heating at $80{ }^{\circ} \mathrm{C}$, was either $100 \%$ or close to $100 \%$ for all $\mathrm{pH}$ values studied (from 2 to 10), except for $\mathrm{pH} 6$ where it reached $93.87 \%$. For the $\mathrm{PI}_{10.5-2.5}$, decreases in the emulsion stability were observed at $\mathrm{pH} 8(85.71 \%)$ and $\mathrm{pH} 10(53.15 \%)$. In the entire concentration range, the $\mathrm{PI}_{10.5-2.5}$ exhibited a higher scavenging ability on 2,2-diphenyl-1-picryl hydrazyl (DPPH) and hydroxyl radicals than $\mathrm{PI}_{2.5-8.5}$ as evaluated by DPPH and 2-deoxyribose assays, respectively. At the highest concentration studied, $1.0 \%$, the neutralization of DPPH radicals by $\mathrm{PI}_{10.5-2}$ reached half of that exhibited by synthetic antioxidant butylhydroxytoluene $(82.65 \%)$. At the same concentration, the inhibition of hydroxyl radicals by $\mathrm{PI}_{10.5-2}(71.25 \%)$ was close to that achieved by mannitol $(75.62 \%)$, which was used as a positive control. Established antioxidant capacities add value to the protein isolates that can thus be used as both emulsifiers and antioxidants.
\end{abstract}

Keywords: rapeseed; sequential isoelectric precipitation; multifunctionality; protein isolates; antioxidant capacity

\section{Introduction}

Rapeseed oil is a valuable commodity widely used in the food industry [1] or other industrial sectors to produce biofuel, paper, textile, plastics, lubricants, and surfactants [2,3]. It is also used in agriculture for dust masking in swine barns [4] or as a biopesticide [5]. The enhanced demand for this vegetable oil worldwide results in high amounts of rapeseed meal as a by-product, which reached 38.8 million tons in 2018 [6] and 40 million tons in 2020 [7].

Currently, rapeseed meal has an underestimated application. Mainly, it is used as an inexpensive protein-rich ingredient in feed formulation [8,9]. However, the presence of substantial amounts of glucosinolates, tannins, and fibres limits the inclusion of the meal because of their negative effect on animal growth and physiology [10].

Alternatively, rapeseed meal could be used as a source for preparing protein isolates/concentrates. Recently, there has been an increasing interest in plant proteins. The global demand for protein is driven by various factors such as population growth, increases in urbanization and ageing, and altered customers' preferences which are recently directed 
to a vegetable type of foods as a prerequisite for a healthy style of living [11]. In addition, the production of animal-based foods is associated with higher levels of greenhouse gases than plant-based foods, which reflects climate change [12,13].

Rapeseed protein isolates are "novel foods" introduced to the human diet [14]. However, they possess desired nutritional and functional characteristics that are highly dependent on raw material characteristics, seed processing, and protein isolate preparation mode $[15,16]$. Most protein isolates are prepared by isoelectric precipitation in the acidic $\mathrm{pH}$ area, where they exhibit the lowest solubility [17-20]. A low solubility limits protein isolate functionality and subsequent application. Kalaydzhiev et al. [21] used a different approach, i.e., sequential isoelectric precipitation, and obtained two protein isolates from industrial rapeseed meal with enhanced solubility. Protein solubility is a crucial determinant of remaining functional properties, and plant proteins with such a characteristic would be a value added to the food, agricultural, and pharmaceutical industries. These two protein isolates also contain phenols that could contribute to their functionality and overall benefits, although increasing their impurity. The protein isolates functional properties combined with the phenols antioxidant capacity may turn them into bioactive ingredients with multi-functional features [22,23].

The current study continues the previous one [21] aiming to evaluate the potential applicability of the newly obtained rapeseed meal protein isolates as multifunctional ingredients. For this purpose, water and oil absorption capacity and emulsifying properties at two boundary concentrations of $\mathrm{NaCl}(0.03$ and $0.25 \mathrm{M})$ in a wide $\mathrm{pH}$ range (2.0-10.0), were determined. Antioxidant capacities were estimated by three methods differing by their principles, namely 2,2-diphenyl-1-picryl hydrazyl (DPPH), ferric reducing antioxidant power (FRAP), and 2-deoxy-D-ribose assays to better reveal the practical value of the isolates.

\section{Materials and Methods}

\subsection{Materials}

Rapeseed meal was manufactured and kindly donated by a local processing factory (OLIVA AD, Polski Trambesh, Bulgaria). All analytical grade reagents were from Merck KGaA (Darmstadt, Germany) via Fillab (Plovdiv, Bulgaria), and water used in all analyses was distilled.

\subsection{Preparation of Protein Isolates}

Protein isolates were prepared from industrially manufactured rapeseed meal as previously described [21]. Briefly, the meal was ground and sieved. Uniformly sized particles $(\leq 0.315 \mathrm{~mm})$ were subjected to a 4 -fold treatment with a $75 \%$ aqueous ethanol solution $(v / v)$. The ethanol-treated rapeseed meal was further used to extract proteins at $\mathrm{pH} 12\left(40{ }^{\circ} \mathrm{C}, 60 \mathrm{~min}\right)$. Two protein isolates were prepared by a vice versa sequence of precipitation at multiple $\mathrm{pH}$ values. The protein isolate $\mathrm{PI}_{10.5-2.5}$ was obtained by sequential precipitation of the proteins from the extract starting at $\mathrm{pH} 10.5$ to 2.5 by lowering the $\mathrm{pH}$ by one unit. The second one, $\mathrm{PI}_{2.5-8.5}$, was obtained after a sharp decrease in extract $\mathrm{pH}$ to 2.5 , followed by an increase in the $\mathrm{pH}$ to 8.5 with one unit. The $\mathrm{pH}$ was adjusted by using either $\mathrm{NaOH}$ or $\mathrm{HCl}$ as needed. The precipitates, obtained at each $\mathrm{pH}$ value, were collected by centrifugation (6000 rpm), lyophilized (Lyovac GT2, Leybold-Heraeus, Köln, Germany), and mixed to prepare the powdery protein isolates, $\mathrm{PI}_{2.5-8.5}$ or $\mathrm{PI}_{10.5-2.5}$. The procedure is schematically outlined in Figure 1. 


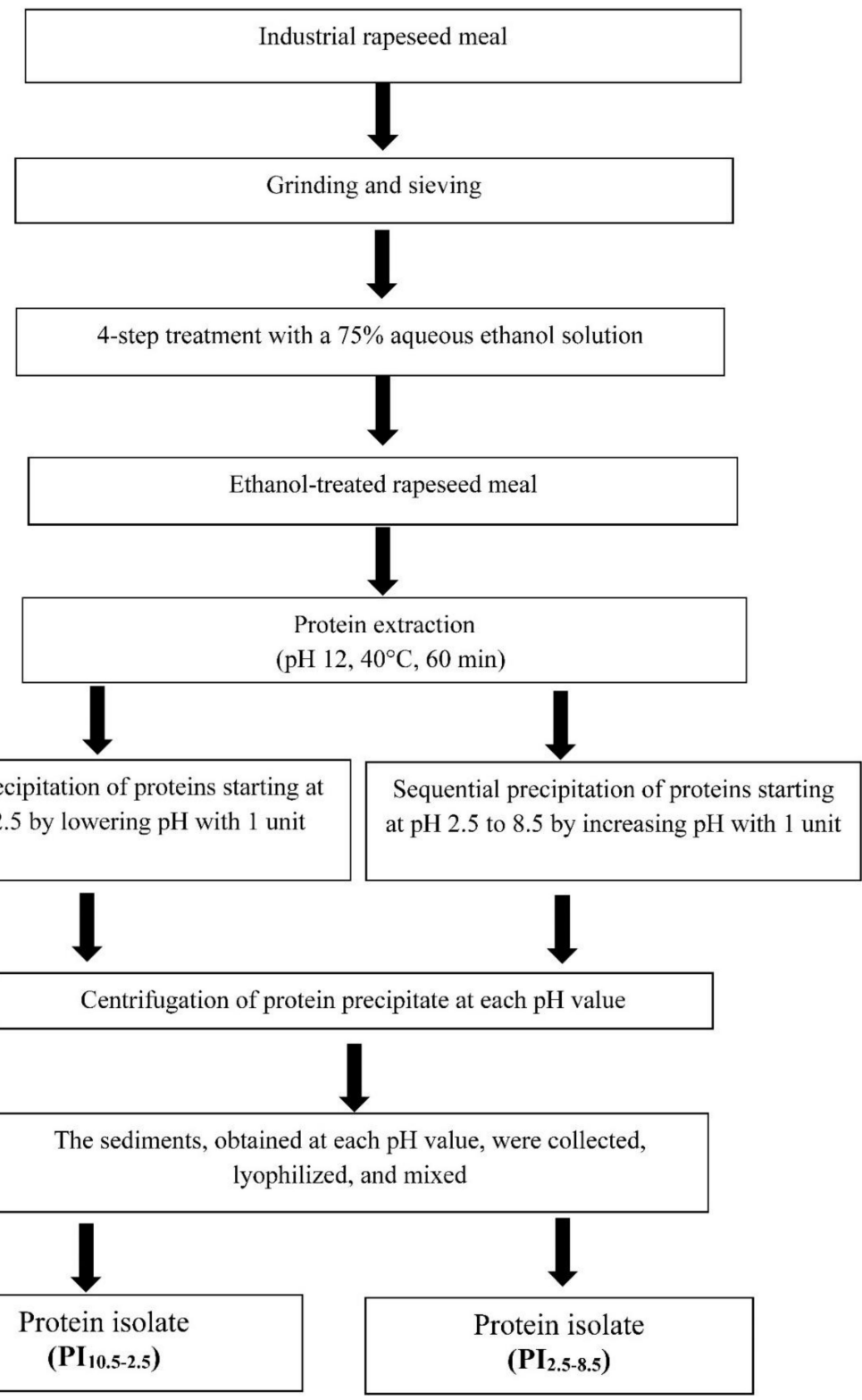

Figure 1. Preparation of protein isolates, $\mathrm{PI}_{2.5-8.5}$ and $\mathrm{PI}_{10.5-2.5}$, from ethanol-treated rapeseed meal.

\subsection{Techno-Functional Properties of $\mathrm{PI}_{2.5-8.5}$ and $\mathrm{PI}_{10.5-2.5}$}

\subsubsection{Determination of Water and Oil Absorption Capacity}

Water absorption capacity (WAC) was determined as described by Rodriguez-Ambriz et al. [24]. A $100 \mathrm{mg}$ protein sample was mixed with $1 \mathrm{~mL}$ distilled water and vortexed (Advanced Vortex Mixer-ZX3, VELP Scientifica, Usmate Velate, Italy) for $30 \mathrm{~s}$. The resulting suspension was incubated at room temperature $\left(23^{\circ} \mathrm{C}\right)$ for $30 \mathrm{~min}$ and centrifuged for $20 \mathrm{~min}$ at $1800 \times g(\mathrm{MPW}-251$, Med. Instruments, Warsaw, Poland). The supernatant was decanted for $10 \mathrm{~min}$ at a 45 -degree angle. WAC was calculated by dividing the weight of the absorbed water $(\mathrm{g})$ by the weight of the protein sample $(\mathrm{g})$.

Oil absorption capacity (OAC) was determined by the method of Lin and Zayas [25]. Each protein sample $(100 \mathrm{mg}$ ) was mixed with $1 \mathrm{~mL}$ sunflower oil and vortexed (Advanced Vortex Mixer-ZX3, VELP Scientifica, Usmate (MB), Italy) for $30 \mathrm{~s}$. The mixture was incubated at room temperature $\left(23^{\circ} \mathrm{C}\right)$ for $30 \mathrm{~min}$ and subsequently centrifuged at $13,600 \times g$ for 10 min (MPW-251, Med. Instruments, Warsaw, Poland). The supernatant was decanted and drained for $20 \mathrm{~min}$ at a 45-degree angle. OAC was calculated by dividing the weight of the absorbed oil $(\mathrm{g})$ by the weight of the protein sample $(\mathrm{g})$. 
The influence of $\mathrm{NaCl}$ on WAC and OAC of the protein isolates was evaluated by adding the salt to the test systems to final concentrations of 0.03 or $0.25 \mathrm{M}$ wherever needed.

\subsubsection{Emulsifying Properties}

Emulsifying activity and emulsion stability were determined as described by Neto et al. [26]. A $5 \mathrm{~mL}$ sample solution containing $0.5 \mathrm{mg}$ protein $/ \mathrm{mL}$ water was homogenized with $5 \mathrm{~mL}$ sunflower oil for $60 \mathrm{~s}$ at $1000 \mathrm{rpm}$ (Ultra Turrax IKA T18 Basic, Staufen, Germany). The emulsion was centrifuged at $1100 \times g$ for $5 \mathrm{~min}$, and the height of the emulsified layer was measured. The emulsifying activity was calculated as a ratio of the height of the emulsified layer and the height of the total content of the tube and multiplied by 100 to express in percentage.

Emulsion stability was evaluated after heating at $80^{\circ} \mathrm{C}$. A mixture of $5 \mathrm{~mL}$ sample solution $(0.5 \mathrm{mg}$ protein/mL water) and $5 \mathrm{~mL}$ sunflower oil was homogenized for $60 \mathrm{~s}$ at $1000 \mathrm{rpm}$ (Ultra Turrax IKA T18 Basic, Staufen, Germany). The emulsion was heated up to $80^{\circ} \mathrm{C}$ in a water bath (WNB 29, Memmert GmbH + Co.KG, Schwabach, Germany) and maintained under the same conditions for $30 \mathrm{~min}$. Subsequently, it was cooled down to room temperature $\left(22^{\circ} \mathrm{C}\right)$ and centrifuged at $1100 \times g$ for $5 \mathrm{~min}(\mathrm{MPW}-251$, Med. Instruments, Warsaw, Poland). Emulsion stability was calculated by the ratio of the height of the emulsified layer after and before heating measured after centrifugation at $1100 \times g$ for $5 \mathrm{~min}$. $\mathrm{NaCl}$ was added to a test system to reach a final concentration of either $0.03 \mathrm{M}$ or $0.25 \mathrm{M}$ as appropriate. The influence of $\mathrm{pH}$ on emulsifying properties was tested by varying $\mathrm{pH}$ from 2 to 10 with an increment of 2 using $\mathrm{NaOH}$ or $\mathrm{HCl}$.

\subsection{Antioxidant Properties}

\subsubsection{Determination of Total Flavonoid Content}

Total flavonoid contents in $\mathrm{PI}_{2.5-8.5}$ or $\mathrm{PI}_{10.5-2.5}$ were determined by the aluminium nitrate colorimetric method described by Kivrak et al. [27]. An aliquot of $1 \mathrm{~mL}$ protein sample (1\% in distilled water, $\mathrm{pH} 7)$ was mixed with $0.1 \mathrm{~mL} 10 \%$ aluminium nitrate and $0.1 \mathrm{~mL}$ potassium acetate $(1 \mathrm{M})$. An aliquot of $3.8 \mathrm{~mL}$ of distilled water $(\mathrm{pH} 7)$ was added to the mixture to obtain a total volume of $5 \mathrm{~mL}$. The mixture was vortexed, and the absorbance was measured after $40 \mathrm{~min}$ (room temperature) at $415 \mathrm{~nm}$ using a spectrophotometer (Spekol 11; Carl Zeiss Jena, Jena, Germany). The total flavonoid content was calculated from a calibration curve constructed with quercetin. The results were obtained as quercetin equivalents (mg) per $100 \mathrm{~g}$ dry weight sample and expressed in percentage.

\subsubsection{Antioxidant Activity}

The antioxidant potential of $\mathrm{PI}_{2.5-8.5}$ or $\mathrm{PI}_{10.5-2.5}$ to scavenge $\mathrm{DPPH}$ radicals was evaluated considering concentrations varying from $0.2 \%$ to $1.0 \%$ in water $(\mathrm{pH} 7)$ with an increment of 0.2. As described by Dimov et al. [28], the analysis was performed with some modifications. Briefly, $0.15 \mathrm{~mL}$ isolate sample was mixed with $2.85 \mathrm{~mL} 0.06 \mathrm{mM}$ DPPH new solution in $96 \%$ ethanol. The mixtures were kept at room temperature in darkness, and the absorbance (A) was measured at $517 \mathrm{~nm}$ with a spectrophotometer (Spekol 11; Carl Zeiss Jena, Jena, Germany) after $30 \mathrm{~min}$. Antiradical activity (AA) was calculated by using the formula $\mathrm{AA}=\left(\mathrm{A}_{\text {control }}-\mathrm{A}_{\text {sample }}\right) / \mathrm{A}_{\text {control }}$ and multiplied by 100 to express in percentage. The control was treated as the corresponding sample but without adding protein isolates. The synthetic antioxidant butylhydroxytoluene (BHT) was used as a positive control in the same concentrations as for the samples.

Ferric Reducing Antioxidant Power (FRAP) assay was performed as described by Ivanov et al. [29]. Briefly, a $3 \mathrm{~mL}$ freshly prepared FRAP reagent [30] was mixed with $0.1 \mathrm{~mL}$ $1 \% \mathrm{PI}_{2.5-8.5}$ or $\mathrm{PI}_{10.5-2.5}$ prepared in water ( $\left.\mathrm{pH} 7\right)$. The mixture was maintained in the dark for $10 \mathrm{~min}\left(37^{\circ} \mathrm{C}\right)$, and the absorbance $(\mathrm{A})$ was measured at $593 \mathrm{~nm}$ against blank prepared with water and no sample addition. A standard curve was built with $\mathrm{FeSO}_{4} \cdot 7 \mathrm{H}_{2} \mathrm{O}$. Results were calculated by using the following equation: $\mathrm{A}=0.553 \mathrm{x}-0.022$. The results of FRAP analysis were expressed as $\mu \mathrm{mol} \mathrm{Fe}^{2+}$ equivalents per gram dry weight protein isolate [31]. 
Hydroxyl radical scavenging capacity of $\mathrm{PI}_{2.5-8.5}$ or $\mathrm{PI}_{10.5-2.5}$ was evaluated by 2-deoxyD-ribose method as previously described [30]. Briefly, the reaction mixture contained $100 \mu \mathrm{L}$ of $28 \mathrm{mM}$ 2-deoxy-D-ribose (dissolved in $10 \mathrm{mM} \mathrm{KH}_{2} \mathrm{PO}_{4}-\mathrm{K}_{2} \mathrm{HPO}_{4}$ buffer, pH 7.4), $500 \mu \mathrm{L}$ $\mathrm{PI}_{2.5-8.5}$ or $\mathrm{PI}_{10.5-2.5}$ water solutions ( $\mathrm{pH} 7$ ) with varying concentrations from $0.2 \%$ to $1.0 \%$ with an increment of $0.2,200 \mu \mathrm{L}$ of $200 \mu \mathrm{M} \mathrm{FeCl}_{3}$ and $1.04 \mathrm{mM}$ ethylenediaminetetraacetic acid $(1: 1 \mathrm{v} / \mathrm{v})$ mixed prior to addition, $100 \mu \mathrm{L}$ of $10 \mathrm{mM} \mathrm{H}_{2} \mathrm{O}_{2}$ and $100 \mu \mathrm{L}$ of $1 \mathrm{mM}$ ascorbate. The solutions were prepared freshly, and de-aerated water was used for easily oxidizing chemicals. After incubation for $1 \mathrm{~h}$ at $37^{\circ} \mathrm{C}, 1 \mathrm{~mL}$ thiobarbituric acid $(1 \%$ in $50 \mathrm{mM} \mathrm{NaOH})$ and $1 \mathrm{~mL}$ trichloroacetic acid $(2.8 \%$ in water) were added, and the tubes were boiled $\left(100{ }^{\circ} \mathrm{C}\right)$ for $20 \mathrm{~min}$. After cooling, the developed pink chromogen was measured at $532 \mathrm{~nm}$ (A) against the appropriate blank (containing only buffer and deoxyribose). Inhibition (in percentage) was calculated by the formula $\mathrm{I}(\%)=100-\left(\mathrm{A}_{\text {sample }} / \mathrm{A}_{\text {neg.control }}\right) \times 100$. The negative control contained the reaction mixture with the respective volume of water but not a protein isolate. Mannitol was used as a positive control [32] in the same concentrations as for the samples.

\subsection{Statistical Evaluation}

Presented data are the mean \pm standard deviation (SD) of three independent experiments $(n=3)$. Data were analysed by one-way analysis of variance (ANOVA) using Statgraphics Centurion statistical program (version XVI, 2009) (Stat Point Technologies, Ins., Warrenton, VA, USA). Mean differences were established by Fisher's least significant difference test for paired comparison with a significance level $\alpha=0.05$.

\section{Results and Discussion}

\subsection{Preparation of Protein Isolates}

Most plant proteins have isoelectric points in a low acidic region of $\mathrm{pH} 4.5$ to 6 [33]. Rapeseed proteins are unique in having a wide range of isoelectric points [15,34]. According to Lönnerdal and Janson [35], 20\% to $40 \%$ of the rapeseed proteins had isoelectric points close to $\mathrm{pH} 11$, while the remaining proteins were in the range of $\mathrm{pH} 4$ to 8 . The two major rapeseed protein constituents, cruciferin and napin, have the lowest solubility at around pH 7.2 and 10.5, respectively [36]. Thus, the sequential precipitates of the ethanol-treated rapeseed meal protein extract were mixtures of proteins with different isoelectric points, biochemical compositions, and protein profiles as previously evaluated [21]. The authors speculated that the $\mathrm{PI}_{10.5-2.5}$, having a precipitation onset at $\mathrm{pH} 10.5$, contained a higher amount of napin and less cruciferin than $\mathrm{PI}_{2.5-8.5}$, which explained the better solubility of the $\mathrm{PI}_{10.5-2.5}$ in the acidic $\mathrm{pH}$ region [21]. The two protein isolates exhibited a solubility behaviour different from that of the protein isolate obtained at a single $\mathrm{pH}$ value [37]. The presence of proteins with miscellaneous structures and physicochemical properties as well as phytochemicals with bioactive properties in the $\mathrm{PI}_{2.5-8.5}$ or $\mathrm{PI}_{10.5-2.5}$ assume multifunctional features of the isolates.

\subsection{Techno-Functional Properties of $\mathrm{PI}_{2.5-8.5}$ and $\mathrm{PI}_{10.5-2.5}$ \\ 3.2.1. Water- and Oil Absorption Capacities}

The $\mathrm{PI}_{10.5-2.5}$ exhibited higher water and oil absorption capacities than $\mathrm{PI}_{2.5-8.5}$ under all conditions studied (Table 1). WAC and OAC are closely related to protein concentration [38,39], and obtained results were unexpected. The $\mathrm{PI}_{10.5-2.5}$ contained a lower amount of crude protein $(68.67 \%)$ than $\mathrm{PI}_{2.5-8.5}(72.84 \%)$ [21], but the structure, amino acid composition, and conformation of the individual protein molecules mobilized at water/oil should also be considered [40]. According to Ntone et al. [41], napin has a stronger interaction with water/oil molecules than cruciferin due to its specific Janus-like structure, where $45 \%$ of hydrophobic amino acids are located at one side of the protein. In contrast, cruciferin, a bigger molecule, has a lower diffusion rate and more even distribution of hydrophobic and hydrophilic domains, leading to a weaker interaction with molecules with different polarities. The addition of $\mathrm{NaCl}$ did not influence the $\mathrm{WAC}$ of $\mathrm{PI}_{2.5-8.5}$ and 
$\mathrm{PI}_{10.5-2.5}$ (Table 1). It might be related to the impurity of both isolates. Ivanova et al. [39] established high sensitivity of WAC of the protein isolate with high protein content $(94.25 \%)$ to $\mathrm{NaCl}$ addition but not of the one with lower protein concentration $(75.34 \%)$. The WAC of the latter was not modulated by either $\mathrm{NaCl}$ supplementation level, 0.03 or $0.25 \mathrm{M}$. The two levels of $\mathrm{NaCl}$ supplementation were chosen as the most employed boundary salt concentrations in food formulation [42].

Table 1. Water and oil absorption capacity of $\mathrm{PI}_{2.5-8.5}$ and $\mathrm{PI}_{10.5-1.5}$ at different concentrations of $\mathrm{NaCl}$.

\begin{tabular}{|c|c|c|c|c|c|c|}
\hline \multirow{3}{*}{ Sample } & \multicolumn{3}{|c|}{$\begin{array}{l}\text { Water Absorption Capacity } \\
\qquad\left(\mathrm{g} \mathrm{H}_{2} \mathrm{O} / \mathrm{g} \mathrm{Sample}\right)\end{array}$} & \multicolumn{3}{|c|}{$\begin{array}{l}\text { Oil Absorption Capacity } \\
\text { (g oil/g Sample) }\end{array}$} \\
\hline & \multicolumn{3}{|c|}{$\mathrm{NaCl}$ Concentration, $\mathrm{M}$} & \multicolumn{3}{|c|}{$\mathrm{NaCl}$ Concentration, $\mathrm{M}$} \\
\hline & 0 & 0.03 & 0.25 & 0 & 0.03 & 0.25 \\
\hline $\mathrm{PI}_{2.5-8.5}$ & $2.11 \pm 0.00^{\mathrm{a}, \mathrm{B}}$ & $2.25 \pm 0.06^{\mathrm{a}, \mathrm{B}}$ & $2.23 \pm 0.05^{\mathrm{a}, \mathrm{B}}$ & $1.68 \pm 0.01^{\mathrm{c}, \mathrm{B}}$ & $1.73 \pm 0.01^{\mathrm{b}, \mathrm{B}}$ & $1.90 \pm 0.01^{\mathrm{a}, \mathrm{B}}$ \\
\hline $\mathrm{PI}_{10.5-2.5}$ & $2.36 \pm 0.12^{\mathrm{a}, \mathrm{A}}$ & $2.42 \pm 0.09^{\mathrm{a}, \mathrm{A}}$ & $2.68 \pm 0.09^{a, A}$ & $2.03 \pm 0.03 \mathrm{~b}, \mathrm{~A}$ & $2.05 \pm 0.03 \mathrm{~b}, \mathrm{~A}$ & $2.36 \pm 0.04^{\mathrm{a}, \mathrm{A}}$ \\
\hline
\end{tabular}

${ }^{\mathrm{a}-\mathrm{c}}$ Means in a row for a particular functional property without a common lower case letter differ significantly $(p<0.05) .{ }^{A}, \mathrm{~B}$ Means in a column without a common capital letter differ significantly $(p<0.05)$.

The ability of proteins to absorb water/oil is an important determinant of texture and mouth feel characteristics of food products [43]. The WAC of $\mathrm{PI}_{2.5-8.5}$ and $\mathrm{PI}_{10.5-2.5}$ (Table 1) was comparable to the one of other plant protein isolates/concentrates prepared from okra [44], cashew nut [45], and pigeon pea [46]. The OAC of $\mathrm{PI}_{2.5-8.5}$ and $\mathrm{PI}_{10.5-2.5}$ (Table 1) was higher than that of flours and protein concentrates or isolates from pulses and soybeans [47] and close to the OAC of the protein-rich products obtained from sunflower meal [39], cashew nut [45], and walnut [48].

\subsubsection{Emulsifying Properties}

Except for $\mathrm{pH} 6,8$, and $10(0.25 \mathrm{M} \mathrm{NaCl})$, the overall emulsifying activity of $\mathrm{PI}_{2.5-8.5}$ was higher than that of $\mathrm{PI}_{10.5-2.5}$ (Table 2). Compared to the emulsifying activity of a rapeseed meal protein isolate prepared by single $\mathrm{pH}$-point precipitation [20], the emulsifying activities of both protein isolates were lower. However, the data demonstrated a weak influence of $\mathrm{pH}$ and $\mathrm{NaCl}$ supplementation. It is most probably due to the mixed composition of the $\mathrm{PI}_{2.5-8.5}$ and $\mathrm{PI}_{10.5-2.5}$, which consisted of proteins with different isoelectric points. Thus, the sequential protein precipitates are more advantageous compared to that obtained at single isoelectric points, which exhibit high sensitivity to $\mathrm{pH}$ variation, with the lowest emulsifying activity being at the isoelectric point $[20,39,45,48]$. The low response of the $\mathrm{PI}_{2.5-8.5}$ and $\mathrm{PI}_{10.5-2.5}$ emulsifying activities to the two factors would allow their application in food systems with a broad $\mathrm{pH}$ range and salt concentration.

Table 2. Emulsifying activity of $\mathrm{PI}_{2.5-8.5}$ and $\mathrm{PI}_{10.5-2.5}$ at different $\mathrm{pH}$ and $\mathrm{NaCl}$ concentrations.

\begin{tabular}{ccccccc}
\hline & & \multicolumn{5}{c}{ Emulsifying Activity, \% } \\
\cline { 3 - 7 } Sample & $\begin{array}{c}\text { NaCl } \\
\text { Concentration }\end{array}$ & \multicolumn{5}{c}{$\mathbf{p H}$} \\
\cline { 3 - 7 } & & $\mathbf{2}$ & $\mathbf{4}$ & $\mathbf{6}$ & $\mathbf{8}$ & $\mathbf{1 0}$ \\
\hline \multirow{2}{*}{$\mathrm{PI}_{2.5-8.5}$} & $0.00 \mathrm{M}$ & $53.85 \pm 0.00^{\mathrm{a}, \mathrm{A}}$ & $51.17 \pm 0.50^{\mathrm{ab}, \mathrm{A}}$ & $55.03 \pm 1.37^{\mathrm{b}, \mathrm{A}}$ & $46.36 \pm 0.44^{\mathrm{ab}, \mathrm{B}}$ & $52.00 \pm 1.88^{\mathrm{a}, \mathrm{A}}$ \\
& $0.03 \mathrm{M}$ & $50.38 \pm 0.53^{\mathrm{ab}, \mathrm{B}}$ & $52.37 \pm 1.07^{\mathrm{a}, \mathrm{B}}$ & $59.18 \pm 0.40^{\mathrm{a}, \mathrm{A}}$ & $49.68 \pm 1.41^{\mathrm{a}, \mathrm{B}}$ & $51.34 \pm 0.02^{\mathrm{a}, \mathrm{B}}$ \\
& $0.25 \mathrm{M}$ & $47.53 \pm 1.48^{\mathrm{b}, \mathrm{A}}$ & $48.53 \pm 0.06^{\mathrm{b}, \mathrm{A}}$ & $45.78 \pm 1.00^{\mathrm{c}, \mathrm{A}}$ & $45.07 \pm 0.00^{\mathrm{b}, \mathrm{A}}$ & $46.54 \pm 2.07^{\mathrm{b}, \mathrm{A}}$ \\
\hline \multirow{3}{*}{$\mathrm{PI}_{10.5-1.5}$} & $0.00 \mathrm{M}$ & $48.92 \pm 1.53^{\mathrm{a}, \mathrm{AB}}$ & $46.51 \pm 1.67^{\mathrm{a}, \mathrm{B}}$ & $45.85 \pm 0.90^{\mathrm{b}, \mathrm{B}}$ & $46.67 \pm 0.00^{\mathrm{b}, \mathrm{AB}}$ & $50.96 \pm 0.41^{\mathrm{a}, \mathrm{A}}$ \\
& $0.03 \mathrm{M}$ & $49.28 \pm 0.00^{\mathrm{a}, \mathrm{AB}}$ & $48.09 \pm 0.56^{\mathrm{a}, \mathrm{AB}}$ & $50.70 \pm 0.98^{\mathrm{a}, \mathrm{A}}$ & $46.95 \pm 1.41^{\mathrm{b}, \mathrm{B}}$ & $46.25 \pm 0.59^{\mathrm{b}, \mathrm{B}}$ \\
& $0.25 \mathrm{M}$ & $44.68 \pm 0.55^{\mathrm{b}, \mathrm{D}}$ & $46.77 \pm 1.50^{\mathrm{a}, \mathrm{CD}}$ & $48.29 \pm 0.40^{\mathrm{ab}, \mathrm{BC}}$ & $51.02 \pm 0.47^{\mathrm{a}, \mathrm{AB}}$ & $53.44 \pm 1.04^{\mathrm{a}, \mathrm{A}}$ \\
\hline
\end{tabular}

${ }^{\mathrm{a}-\mathrm{c}}$ Means in a column for a sample without a common lower case letter differ significantly $(p<0.05)$. ${ }^{\text {A-D }}$ Means in a row without a common capital letter differ significantly $(p<0.05)$. 
The $\mathrm{PI}_{2.5-8.5}$ and $\mathrm{PI}_{10.5-2.5}$ exhibited high emulsion stability $30 \mathrm{~min}$ after heating (Figure 2A,B). The emulsion stability of the $\mathrm{PI}_{2.5-8.5}$ was either $100 \%$ or close to $100 \%$ for all $\mathrm{pH}$ values studied, except for $\mathrm{pH} 6$ where it reached $93.87 \%$ (Figure $2 \mathrm{~A}$ ). This $\mathrm{pH}$ is in the range where most rapeseed proteins precipitate [35]. For the $\mathrm{PI}_{10.5-2.5}$, decreases in the emulsion stability were observed at $\mathrm{pH} 8(85.71 \%)$ and $\mathrm{pH} 10(53.15 \%)$ (no $\mathrm{NaCl}$ addition, Figure 2B). The $\mathrm{NaCl}$ supplementation at these $\mathrm{pH}$ values enhanced the stability of the emulsions yet was lower than that of the $\mathrm{PI}_{2.5-8.5}$ under the same conditions (Figure 2A). With a precipitation onset at $\mathrm{pH} 10.5$, the $\mathrm{PI}_{10.5-2.5}$ contained basic proteins having isoelectric points in the $\mathrm{pH}$ area from 8 to 10 . At the $\mathrm{pH}$ close to the isoelectric points, the total charge of proteins is zero. The proteins tend to be more densely packed due to diminished electrostatic repulsive forces and increased hydrophobic interactions, which facilitate droplet flocculation [49]. This is the initial step leading to destabilization of the emulsion and separation of the phases. Far from the isoelectric point, proteins are charged, which facilitates their interaction at the interface and the formation of a stabilizing viscoelastic layer around oil droplets. A recent study by Östbring et al. [50] confirmed the better stabilizing capacity of rapeseed proteins at $\mathrm{pH}$ values being far from their isoelectric points. Weak emulsification ability near isoelectric points was reported for sunflower protein isolates [51], potato, rice, and pea protein concentrates [52].
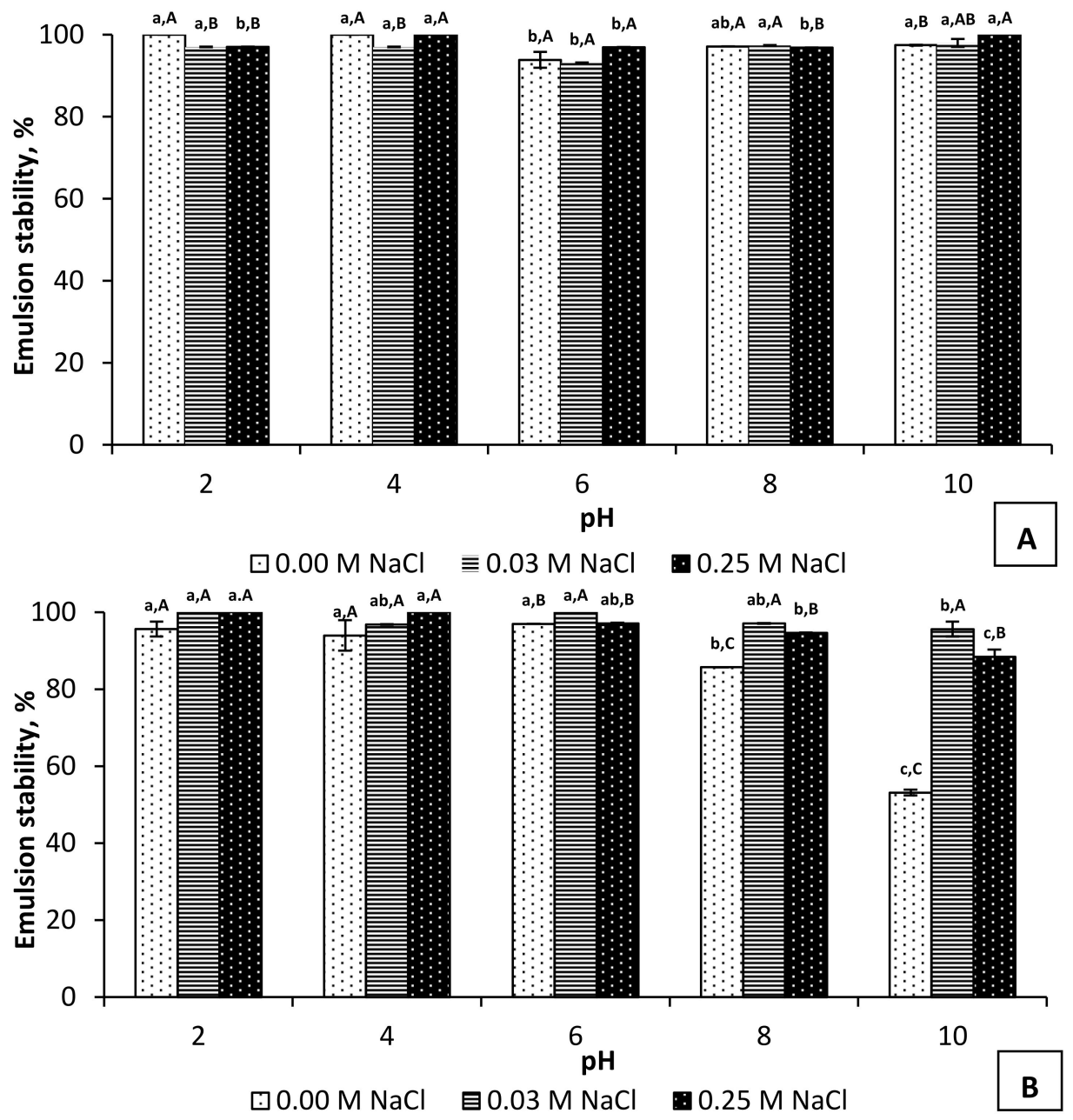

Figure 2. Emulsion stability of $\mathrm{PI}_{2.5-8.5}(\mathbf{A})$ and $\mathrm{PI}_{10.5-1.5}(\mathbf{B})$ at different $\mathrm{pH}$ and $\mathrm{NaCl}$ concentrations. ${ }^{\mathrm{a}-\mathrm{c}}$ Means without the same lowercase letter for a particular $\mathrm{NaCl}$ concentration differ significantly $(p<0.05)$. ${ }^{\text {A-C }}$ Means without the same capital letter for a particular $\mathrm{pH}$ differ significantly $(p<0.05)$. 


\subsection{Antioxidant Properties of $P I_{2.5-8.5}$ and $P I_{10.5-2.5}$}

Three in vitro methods, DPPH, FRAP, and hydroxyl radical scavenging assay, were used to evaluate the antioxidant properties of $\mathrm{PI}_{2.5-8.5}$ and $\mathrm{PI}_{10.5-2.5}$ dissolved in water (pH 7). Application of analytical methods differing by their principles is especially important when natural products, containing various bioactive compounds with potentially different antioxidant mechanisms, are evaluated [53]. Considering the influence of the solvent on antioxidant properties of bioactive compounds [54,55], we performed the investigation with the clear understanding that the results might differ from the maximum antioxidant values that could potentially be achieved if other solvents and $\mathrm{pH}$ were used. However, water is commonly used in food preparation as a solvation agent, and obtained data would be more significant if applicable under industrial conditions.

$\mathrm{PI}_{2.5-8.5}$ and $\mathrm{PI}_{10.5-2.5}$ demonstrated increasing scavenging potential on DPPH radicals with increasing of their concentrations (Figure 3). In the entire concentration range, from 0.2 to $1.0 \%$, the $\mathrm{PI}_{10.5-2.5}$ exhibited a higher antiradical activity than $\mathrm{PI}_{2.5-8.5}$. The highest value was achieved at $1.0 \% \mathrm{PI}_{10.5-2.5}(40.83 \%)$, approximately half of the antiradical activity of BHT $(82.65 \%)$ used as a positive control in the study.

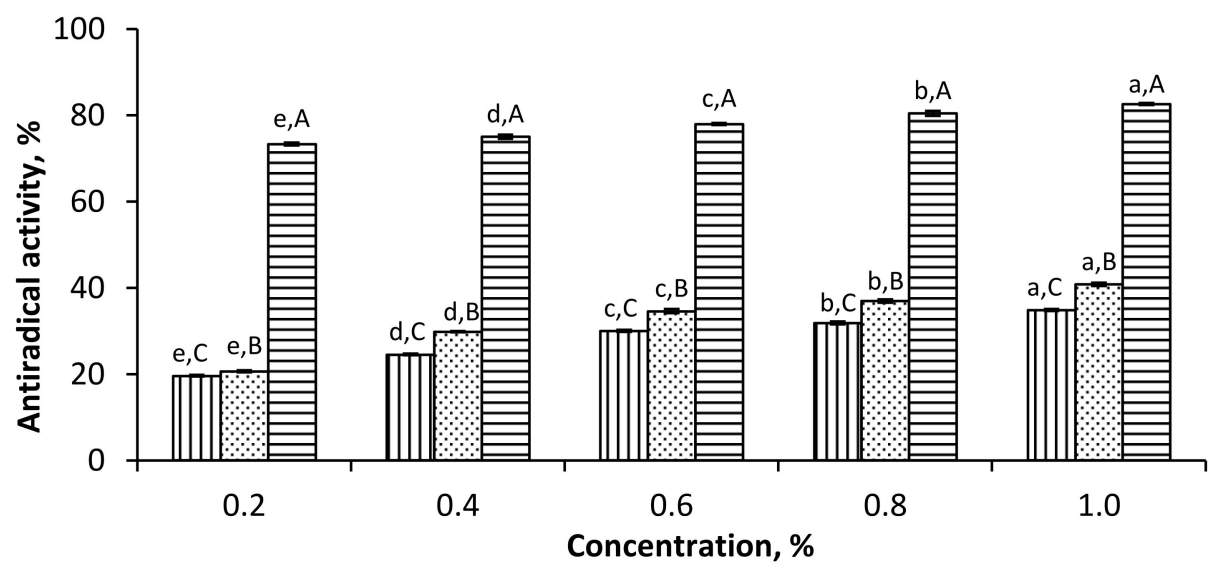

口PI 2.5-8.5 @PI 10.5-2.5 घBHT

Figure 3. Scavenging effect of ethanol-treated rapeseed meal protein isolates, $\mathrm{PI}_{2.5-8.5}$ and $\mathrm{PI}_{10.5-2.5}$, on 2,2-diphenyl-1-picryl hydrazyl (DPPH) radical. ${ }^{\text {a-e }}$ Means of one sample with different concentrations without a common letter differ significantly $(p<0.05)$. ${ }^{\mathrm{A}-\mathrm{C}}$ Means of the samples with the same concentration without a common letter differ significantly $(p<0.05)$.

A similar trend was observed for the hydroxyl radical scavenging activity of the two protein isolates (Figure 4). For all studied concentrations, the $\mathrm{PI}_{10.5-2.5}$ exhibited a higher capacity to neutralize the hydroxyl radicals than $\mathrm{PI}_{2.5-8.5}$. It was maximum at $1 \%$ $\mathrm{PI}_{10.5-2.5}(71.25 \%)$ and close to the inhibition capacity of mannitol at the same concentration $(75.62 \%)$. Based on the neutralizing levels and the relative comparison to the compounds used as positive controls, the $\mathrm{PI}_{10.5-2.5}$ appeared as a better scavenger of hydroxyl than DPPH radicals.

It was established that $\mathrm{PI}_{10.5-2.5}$ contained a higher amount of flavonoids $(0.18 \%)$ than $\mathrm{PI}_{2.5-8.5}$ (0.13\%) (Figure 5). Numerous studies, well reviewed by Treml and Smejkal [56], demonstrated flavonoids as potent scavengers of hydroxyl radicals. This feature is structurerelated, with some crucial elements, namely ring $\mathrm{B}$ hydroxylation, a $\mathrm{C} 2-\mathrm{C} 3$ double bond, a C-4 carbonyl group, and a C-3 hydroxyl group [56]. The hydroxyl radical is one of the most reactive natural free radicals known [56]. This species is highly vulnerable to important biological molecules such as proteins, unsaturated fatty acids, and DNA, as the latter is affected at both primary and secondary structural levels [56]. The two protein isolates, and particularly $\mathrm{PI}_{10.5-2.5}$, appeared as valuable products with the potential to decrease oxidative stress caused by hydroxyl radicals. 


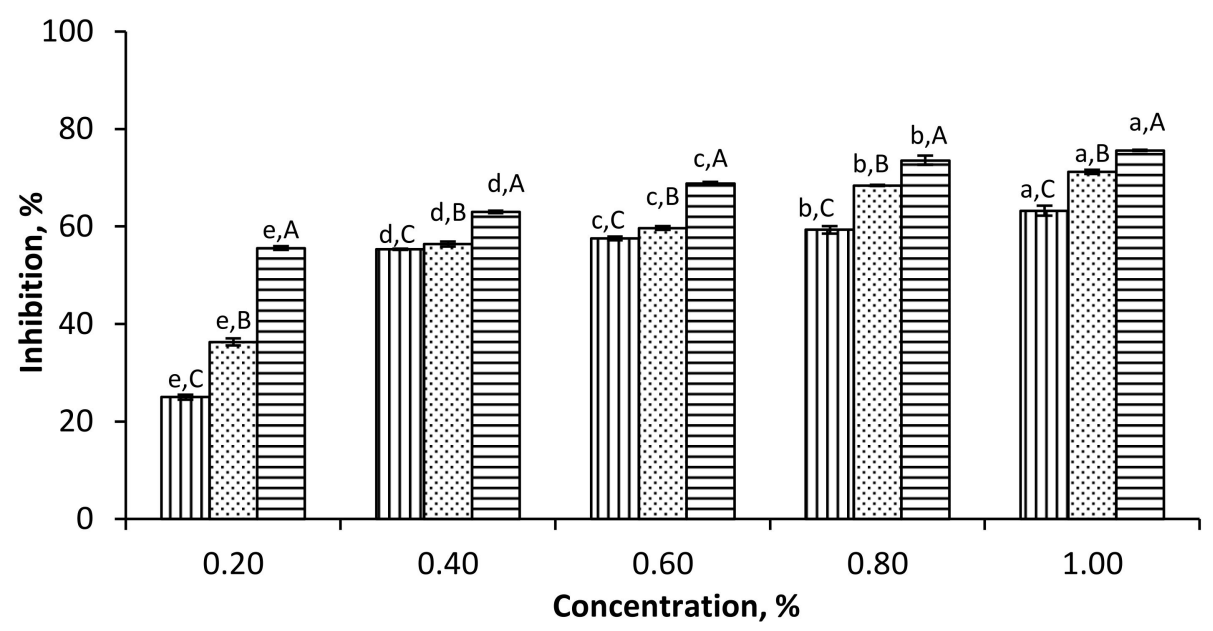

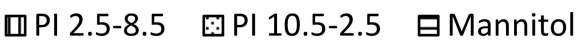

Figure 4. Hydroxyl radical scavenging activity of ethanol-treated rapeseed meal protein isolates, $\mathrm{PI}_{2.5-8.5}$ and $\mathrm{PI}_{10.5-2.5}$. ${ }^{\text {a-e }}$ Means of one sample with different concentrations without a common letter differ significantly $(p<0.05) .{ }^{\mathrm{A}-\mathrm{C}}$ Means of the samples with the same concentration without a common letter differ significantly $(p<0.05)$.

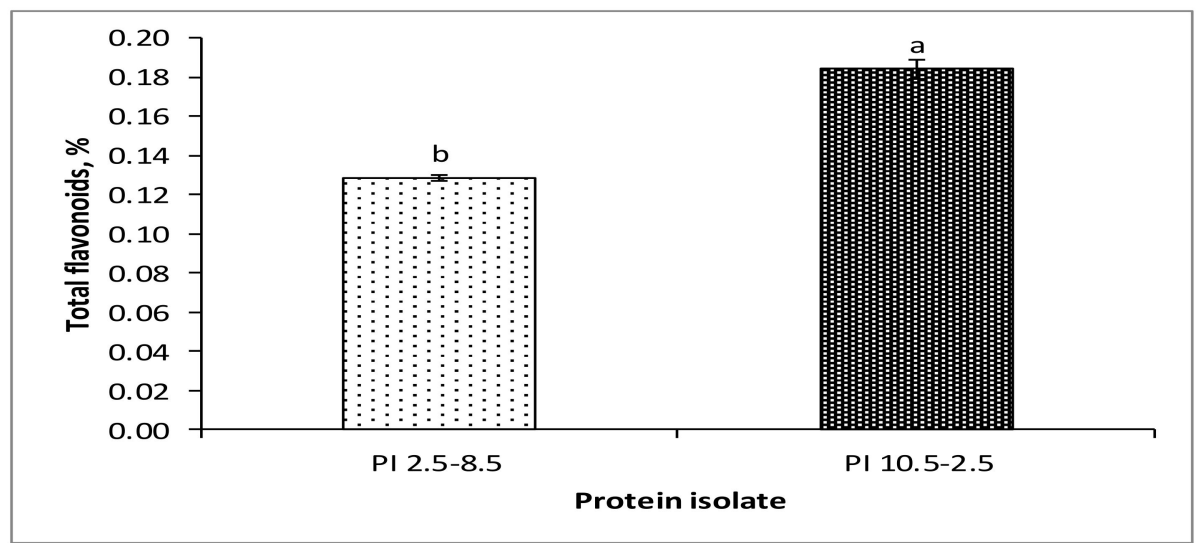

Figure 5. Total flavonoids content of ethanol-treated rapeseed meal protein isolates, $\mathrm{PI}_{2.5-8.5}$ and

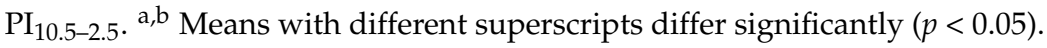

Concerning total phenols, $\mathrm{PI}_{2.5-8.5}$ was the isolate containing a higher amount $(0.71 \%)$ than $\mathrm{PI}_{10.5-2.5}(0.42 \%)$ [21]. Phenols are a large group of secondary plant metabolites with a high antioxidant capacity [53,57]. Although being tempted to relate the total contents of flavonoids or phenols to obtain antioxidant results, such an interpretation might be inaccurate and misleading. Total phenols have been quantified after ultrasound-assisted extraction with $70 \%$ aqueous ethanol solution [21], while the evaluation of the antioxidant capacity was performed after a simple dissolution of the samples in water. Thus, some of the phenols contributing to the total content estimation may not be available for participation in antioxidant reactions of the tests. In addition, the antioxidant properties of the phenols are structure specific, and only the compounds with particular hydroxyl positions in the molecule structure can act as a proton donor [58,59]. da Silva Pereira et al. [60] implied that it was inaccurate to present the antioxidant capacity of a sample as a sum of the antioxidant power of the individual constituents. Phenols and flavonoids tend to bind proteins and form a complex matrix with altered physicochemical properties, including antioxidant ones [61]. Potential synergistic, additive or antagonistic interactions of the single compounds may also influence the total antioxidant potency of natural samples with mixed compositions. 
In contrast to DPPH and hydroxyl radical scavenging assays, $\mathrm{PI}_{2.5-8.5}$ exhibited a better antioxidant capacity than $\mathrm{PI}_{10.5-2.5}$ based on the FRAP measurement approach (Figure 6). This observation might be due to the lower amount of compounds in the $\mathrm{PI}_{10.5-2.5}$ able to donate electrons. While the first two methods involve both electron and hydrogen atom transfer reactions, the FRAP method is based only on a single electron transfer reaction, limiting the range of evaluated compounds. Results obtained by FRAP exclude compounds with antioxidant capacity determined by radical quenching (hydrogen atom transfer) such as thiols [59].

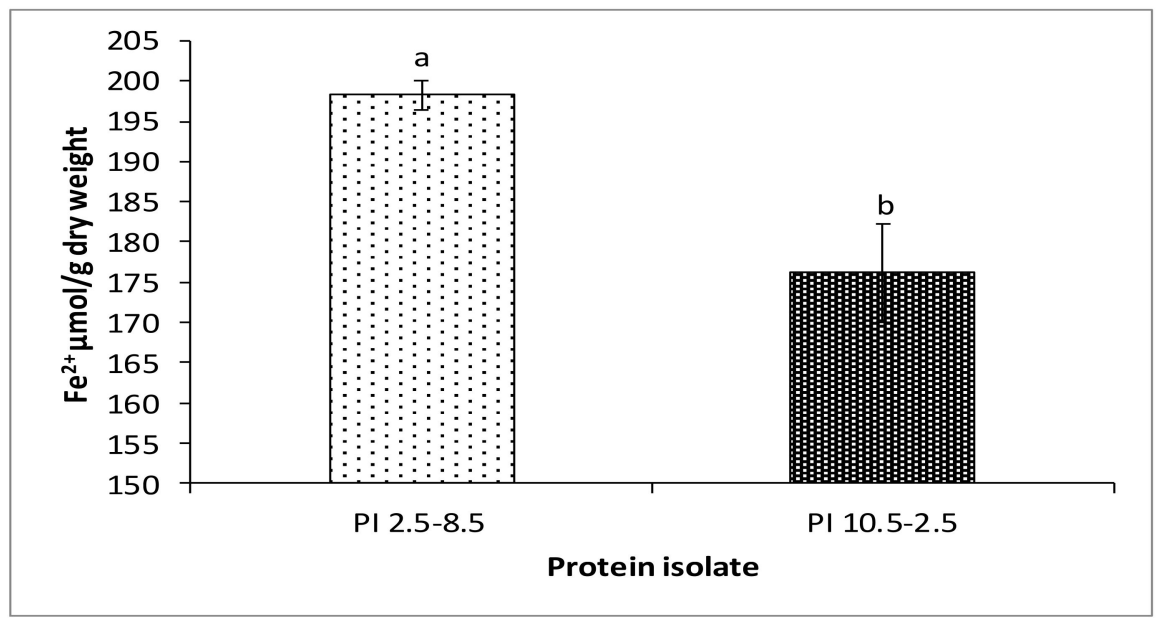

Figure 6. Ferric reducing antioxidant power (FRAP) of ethanol-treated rapeseed meal protein isolates, $\mathrm{PI}_{2.5-8.5}$ and $\mathrm{PI}_{10.5-2.5 \cdot}{ }^{\mathrm{a}, \mathrm{b}}$ Means with different superscripts differ significantly $(p<0.05)$.

Proteins, which are major constituents of $\mathrm{PI}_{2.5-8.5}$ and $\mathrm{PI}_{10.5-2.5}$, are also excluded from the FRAP evaluation [59]. Proteins / peptides were able to donate protons and neutralize free radicals to terminate the radical chain reactions [62]. Durand et al. [63] reported metal chelating activity of the peptides produced from rapeseed meal proteins with Prolyve (a non-specific microbial endoproteinase with subtilisin activity). Yoshie-Stark et al. [64] demonstrated that pepsin-assisted hydrolysates, obtained from rapeseed protein concentrate, had significant scavenging abilities against DPPH radical. Antioxidant properties of rapeseed protein hydrolysates were also established by others [65-67]. While most studies attributed the antioxidant properties to peptides with small molecular weights, Östbring et al. [68] established that non-hydrolysed rapeseed protein precipitates, prepared from five varieties and a mixed blend of cold-pressed rapeseed press cake, were able to reduce lipid oxidation in an emulsion model by using thiobarbituric acid reactive substance assay.

Although rapid, inexpensive, and easy to perform [59], in vitro methods may not provide sufficient estimation of the antioxidant capacity of natural products with a mixed composition such as those of $\mathrm{PI}_{2.5-8.5}$ and $\mathrm{PI}_{10.5-2.5}$. In vivo methods allow for the evaluation not only of their direct ability to scavenge radicals but also to decrease their production in cells and, therefore, should be considered in a future study to complement current findings [56].

Many foods containing lipids require emulsifiers to prevent two immiscible liquids from separating and to provide good appearance and visual acceptance. Such types of food also require the addition of antioxidants to retard lipid oxidation for better quality and extended shelf-life. Protein-phenol complexes contribute to the formation of emulsions with better physical and oxidative stability [23,69]. During homogenization, proteins are oriented at the water-oil interface and form a visco-elastic layer to prevent the emulsion from flocculation and coalescence, while phenols control the co-oxidation of proteins and lipids. Cong et al. [23] demonstrated that the addition of commonly used emulsifiers, such as kaempferol, phloretin, catechin, resveratrol, and hydroxytyrosol, to sodium caseinate, improved the emulsion's free-radical scavenging ability, reducing power and the lipid 
protection effect. Possessing both emulsifying and antioxidant features, the $\mathrm{PI}_{2.5-8.5}$ and $\mathrm{PI}_{10.5-2.5}$ may belong to the group of natural antioxidant emulsifiers, a term being introduced by McClements and Decker [22]. Since the functional properties of the antioxidant emulsifiers are highly dependent on the type of the polyphenols and/or proteins [23,70-72], the compositional complexity of the $\mathrm{PI}_{2.5-8.5}$ and $\mathrm{PI}_{10.5-2.5}$ impose additional analyses to elucidate their synergistic effect on emulsion stability and lipid oxidation. Still, the current study outlined the two products as potential alternatives to synthetic emulsifiers and antioxidants currently used in the food and nutraceutical industries. Although efficient, synthetic additives have raised safety and consumers' preferences for natural products with health-promoting effects. Being reasonably soluble in water and with good emulsifying properties, the $\mathrm{PI}_{2.5-8.5}$ and $\mathrm{PI}_{10.5-2.5}$ would have a broader scope of application as multifunctional ingredients with additional antioxidant properties.

\section{Conclusions}

The study results outlined the $\mathrm{PI}_{2.5-8.5}$ and $\mathrm{PI}_{10.5-2.5}$ as new natural products with beneficial functional properties. In addition to their fair solubility, the $\mathrm{PI}_{2.5-8.5}$ and $\mathrm{PI}_{10.5-2.5}$ exhibited good water and oil absorption capacities. The $\mathrm{PI}_{2.5-8.5}$ and $\mathrm{PI}_{10.5-2.5}$ demonstrated emulsifying properties weakly responding to $\mathrm{pH}$ and $\mathrm{NaCl}$ modulation, which would allow for their potential application in food systems with a broad $\mathrm{pH}$ range and salt concentration. Established antioxidant capacities added value to the protein isolates, which could thus be used as both emulsifiers and antioxidants at a time. The multifunctionality of the protein isolates would contribute to a wider application and, although indirectly, to better and more complete utilization of the rapeseed meal.

Author Contributions: Conceptualization, V.I.C.; methodology, P.I. and V.I.C.; software, P.I. and H.K.; formal analysis, R.G., H.K. and P.I.; data curation, V.I.C.; writing-original draft preparation, V.I.C.; writing-review and editing, C.L.M.S. and P.I.; visualization, R.G., H.K. and P.I.; supervision, V.I.C.; project administration, V.I.C.; funding acquisition, V.I.C. All authors have read and agreed to the published version of the manuscript.

Funding: This research was funded by the BULGARIAN NATIONAL SCIENCE FUND, grant number КП-06-H37/21 "An integrated approach for efficient utilization of by-products of vegetable oil producing industry: Sunflower and rapeseed meals". The APC was provided by C.S.

Data Availability Statement: Data are available on request.

Conflicts of Interest: The authors declare no conflict of interest.

Sample Availability: Samples of the compounds are available from the authors.

\section{References}

1. Raboanatahiry, N.; Li, H.; Yu, L.; Li, M. Rapeseed (Brassica napus): Processing, Utilization, and Genetic Improvement. Agronomy 2021, 11, 1776. [CrossRef]

2. Piazza, G.J.; Foglia, T.A. Rapeseed oil for oleochemical usage. Eur. J. Lipid Sci. Technol. 2001, 103, 450-454. [CrossRef]

3. Aukema, H.; Campbell, L. Oil nutrition and utilization. In Canola: Chemistry, Production, Processing, and Utilization; Daun, J.K., Michael, E.N.A., Hickling, D., Eds.; Elsevier: Amsterdam, The Netherlands, 2011; pp. 245-280. [CrossRef]

4. Senthilselvan, A.; Zhang, Y.; Dosman, J.A.; Barber, E.M.; Holfeld, L.E.; Kirychuk, S.P.; Cormier, Y.; Hurst, T.S.; Rhodes, C.S. Positive Human Health Effects of Dust Suppression with Canola Oil in Swine Barns. Am. J. Respir. Crit. Care Med. 1997, 156, 410-417. [CrossRef] [PubMed]

5. Jaastad, G. Late dormant rapeseed oil treatment against black cherry aphid and cherry fruit moth in sweet cherries. J. Appl. Entomol. 2007, 131, 284-288. [CrossRef]

6. Heuzé, V.; Tran, G.; Sauvant, D.; Lessire, M.; Lebas, F. Rapeseed Meal. Feedipedia, a Programme by INRAE, CIRAD, AFZ and FAO. 2020. Available online: https:/ / www.feedipedia.org/node/52 (accessed on 20 June 2020).

7. USDA, United States Department of Agriculture. Foreign Agricultural Service, Oilseeds and Products Annual, EU Oilseeds Report Annual 2020, Global Agricultural Information Network, Vienna 15 April 2021. Report Number: E42021-0036. Available online: https:/ / www.fas.usda.gov/data/european-union-oilseeds-and-products-annual-1 (accessed on 18 January 2022).

8. Fu, Z.; Su, G.; Yang, H.; Sun, Q.; Zhong, T.; Wang, Z. Effects of Dietary Rapeseed Meal on Growth Performance, Carcass Traits, Serum Parameters, and Intestinal Development of Geese. Animals 2021, 11, 1488. [CrossRef] [PubMed] 
9. Le, D.T.; Chu, H.D.; Le, N.Q. Improving Nutritional Quality of Plant Proteins Through Genetic Engineering. Curr. Genom. 2016, 17, 220-229. [CrossRef]

10. Nega, T. Review on Nutritional Limitations and Opportunities of using Rapeseed Meal and other Rape Seed by-Products in Animal Feeding. J. Nutr. Health Food Eng. 2018, 8, 1. [CrossRef]

11. Henchion, M.; Hayes, M.; Mullen, A.M.; Fenelon, M.; Tiwari, B. Future Protein Supply and Demand: Strategies and Factors Influencing a Sustainable Equilibrium. Foods 2017, 6, 53. [CrossRef]

12. Tilman, D.; Clark, M. Global diets link environmental sustainability and human health. Nature 2014, 515, 518-522. [CrossRef]

13. Scarborough, P.; Appleby, P.N.; Mizdrak, A.; Briggs, A.; Travis, R.C.; Bradbury, K.; Key, T.J. Dietary greenhouse gas emissions of meat-eaters, fish-eaters, vegetarians and vegans in the UK. Clim. Chang. 2014, 125, 179-192. [CrossRef]

14. van der Spiegel, M.; Noordam, M.; van der Fels-Klerx, H. Safety of Novel Protein Sources (Insects, Microalgae, Seaweed, Duckweed, and Rapeseed) and Legislative Aspects for Their Application in Food and Feed Production. Compr. Rev. Food Sci. Food Saf. 2013, 12, 662-678. [CrossRef] [PubMed]

15. Tan, S.H.; Mailer, R.J.; Blanchard, C.L.; Agboola, S.O. Canola Proteins for Human Consumption: Extraction, Profile, and Functional Properties. J. Food Sci. 2011, 76, R16-R28. [CrossRef] [PubMed]

16. Wanasundara, J.P.; McIntosh, T.C.; Perera, S.P.; Withana-Gamage, T.S.; Mitra, P. Canola/rapeseed protein-functionality and nutrition. OCL 2016, 23, D407. [CrossRef]

17. Pedroche, J.; Yust, M.D.M.; Lqari, H.; Giron-Calle, J.; Alaiz, M.; Vioque, J.; Millán, F. Brassica carinata protein isolates: Chemical composition, protein characterization and improvement of functional properties by protein hydrolysis. Food Chem. 2004, 88 337-346. [CrossRef]

18. Yoshie-Stark, Y.; Wada, Y.; Wäsche, A. Chemical composition, functional properties, and bioactivities of rapeseed protein isolates Food Chem. 2008, 107, 32-39. [CrossRef]

19. Das Purkayastha, M.; Gogoi, J.; Kalita, D.; Chattopadhyay, P.; Nakhuru, K.S.; Goyary, D.; Mahanta, C.L. Physicochemical and Functional Properties of Rapeseed Protein Isolate: Influence of Antinutrient Removal with Acidified Organic Solvents from Rapeseed Meal. J. Agric. Food Chem. 2014, 62, 7903-7914. [CrossRef]

20. Kalaydzkiev, H.; Ivanova, P.; Silva, C.; Chalova, V.I. Functional Properties of Protein Isolate and Acid Soluble Protein-Rich Ingredient Co-Produced from Ethanol-Treated Industrial Rapeseed Meal. Pol. J. Food Nutr. Sci. 2019, 69, 129-136. [CrossRef]

21. Kalaydzhiev, H.; Georgiev, R.; Ivanova, P.; Stoyanova, M.; Silva, C.L.M.; Chalova, V.I. Enhanced Solubility of Rapeseed Meal Protein Isolates Prepared by Sequential Isoelectric Precipitation. Foods 2020, 9, 703. [CrossRef]

22. McClements, D.J.; Decker, E. Interfacial Antioxidants: A Review of Natural and Synthetic Emulsifiers and Coemulsifiers That Can Inhibit Lipid Oxidation. J. Agric. Food Chem. 2017, 66, 20-35. [CrossRef]

23. Gong, T.; Tian, D.; Hu, C.Y.; Guo, Y.R.; Meng, Y.H. Improving antioxidant ability of functional emulsifiers by conjugating polyphenols to sodium caseinate. LWT 2021, 154, 112668. [CrossRef]

24. Rodríguez-Ambriz, S.L.; Martínez-Ayala, A.L.; Millán, F.; Dávila-Ortíz, G. Composition and Functional Properties of Lupinus campestris Protein Isolates. Mater. Veg. 2005, 60, 99-107. [CrossRef] [PubMed]

25. Lin, C.S.; Zayas, J.F. Functionality of Defatted Corn Germ Proteins in a Model System: Fat Binding Capacity and Water Retention J. Food Sci. 1987, 52, 1308-1311. [CrossRef]

26. Neto, V.Q.; Narain, N.; Silva, J.B.; Bora, P.S. Functional properties of raw and heat processed cashew nut (Anacardium occidentale, L.) kernel protein isolates. Food/Nahr. 2001, 45, 258-262. [CrossRef]

27. Kivrak, Ş.; Göktürk, T.; Kivrak, I.; Kaya, E.; Karababa, E. Investigation of phenolic profiles and antioxidant activities of some Salvia species commonly grown in Southwest Anatolia using UPLC-ESI-MS/MS. Food Sci. Technol. 2019, 39, 423-431. [CrossRef]

28. Dimov, I.; Petkova, N.; Nakov, G.; Taneva, I.; Ivanov, I.; Stamatovska, V. Improvement of antioxidant potential of wheat flours and breads by addition of medicinal plants. Ukr. Food J. 2018, 7, 671-681. [CrossRef]

29. Ivanov, I.; Vrancheva, R.Z.; Marchev, A.S.; Petkova, N.T.; Aneva, I.Y.; Denev, P.P.; Georgieva, V.G.; Pavlov, A.I. Antioxidant activities and phenolic compounds in Bulgarian Fumaria species. Int. J. Curr. Microbiol. Appl. Sci. 2014, 3, $296-306$.

30. Georgiev, R.; Ivanov, I.G.; Ivanova, P.; Tumbarski, Y.; Kalaydzhiev, H.; Dincheva, I.N.; Badjakov, I.K.; Chalova, V.I. Phytochemical Profile and Bioactivity of Industrial Rapeseed Meal Ethanol-Wash Solutes. Waste Biomass-Valorization 2021, 12, 5051-5063. [CrossRef]

31. Irshad, M.; Zafaryab, M.; Singh, M.; Rizvi, M. Comparative Analysis of the Antioxidant Activity of Cassia fistula Extracts. Int. J. Med. Chem. 2012, 2012, 157125. [CrossRef]

32. Yan, X.; Nagata, T.; Fan, X. Antioxidative activities in some common seaweeds. Mater. Veg. 1998, 52, 253-262. [CrossRef]

33. Sim, S.Y.J.; Srv, A.; Chiang, J.H.; Henry, C.J. Plant Proteins for Future Foods: A Roadmap. Foods 2021, 10, 1967. [CrossRef]

34. Tan, S.H.; Mailer, R.J.; Blanchard, C.L.; Agboola, S.O. Extraction and characterization of protein fractions from Australian canola meals. Food Res. Int. 2011, 44, 1075-1082. [CrossRef]

35. Lönnerdal, B.; Janson, J.-C. Studies on Brassica seed proteins: I. The low molecular weight proteins in rapeseed. Isolation and characterization. Biochim. et Biophys. Acta (BBA)—Protein Struct. 1972, 278, 175-183. [CrossRef]

36. Wanasundara, J.P.D. Proteins ofBrassicaceaeOilseeds and their Potential as a Plant Protein Source. Crit. Rev. Food Sci. Nutr. 2011, 51, 635-677. [CrossRef] [PubMed]

37. Ivanova, P.; Kalaydzhiev, H.; Rustad, T.; Silva, C.L.M.; Chalova, V.I. Comparative biochemical profile of protein-rich products obtained from industrial rapeseed meal. Emir. J. Food Agric. 2017, 29, 170-178. [CrossRef] 
38. Zayas, J.F. Water Holding Capacity of Proteins. In Functionality of Proteins in Food; Springer Science and Business Media LLC: Berlin/Heidelberg, Germany, 1997; pp. 76-133.

39. Functional properties of proteins isolated from industrially produced sunflower meal. Int. J. Food Stud. 2014, 3, 203-212. [CrossRef]

40. Kneifel, W.; Paquin, P.; Abert, T.; Richard, J.-P. Water-Holding Capacity of Proteins with Special Regard to Milk Proteins and Methodological Aspects-A Review. J. Dairy Sci. 1991, 74, 2027-2041. [CrossRef]

41. Ntone, E.; van Wesel, T.; Sagis, L.M.; Meinders, M.; Bitter, J.H.; Nikiforidis, C.V. Adsorption of rapeseed proteins at oil/water interfaces. Janus-like napins dominate the interface. J. Colloid Interface Sci. 2020, 583, 459-469. [CrossRef]

42. Dragoev, S.G.; Vulkova-Yorgova, K.I.; Balev, D.K. Technology of Functional and Special Meat and Fish Products; Minerva: Sofia, Bulgaria, 2008.

43. Okezie, B.O.; Bello, A. Physicochemical and Functional Properties of Winged Bean Flour and Isolate Compared with Soy Isolate. J. Food Sci. 1988, 53, 450-454. [CrossRef]

44. Nnamezie, A.A.; Famuwagun, A.A.; Gbadamosi, S.O. Characterization of okra seed flours, protein concentrate, protein isolate and enzymatic hydrolysates. Food Prod. Process. Nutr. 2021, 3, 1-14. [CrossRef]

45. Ogunwolu, S.O.; Henshaw, F.O.; Mock, H.-P.; Santros, A.; Awonorin, S.O. Functional properties of protein concentrates and isolates produced from cashew (Anacardium occidentale L.) nut. Food Chem. 2009, 115, 852-858. [CrossRef]

46. Aa, O. Emulsification and Foaming Properties of Locust Bean (Parkiabiglobosa) and Pigeon Pea (Cajanuscajan) Seed Flours and their Protein Isolates. Nutr. Food Sci. Int. J. 2017, 2. [CrossRef]

47. Wang, N.; Maximiuk, L.; Fenn, D.; Nickerson, M.T.; Hou, A. Development of a method for determining oil absorption capacity in pulse flours and protein materials. Cereal Chem. 2020, 97, 1111-1117. [CrossRef]

48. Mao, X.; Hua, Y. Composition, Structure and Functional Properties of Protein Concentrates and Isolates Produced from Walnut (Juglans regia L.). Int. J. Mol. Sci. 2012, 13, 1561-1581. [CrossRef] [PubMed]

49. McClements, D.J. Protein-stabilized emulsions. Curr. Opin. Colloid Interface Sci. 2004, 9, 305-313. [CrossRef]

50. Östbring, K.; Matos, M.; Marefati, A.; Ahlström, C.; Gutiérrez, G. The Effect of pH and Storage Temperature on the Stability of Emulsions Stabilized by Rapeseed Proteins. Foods 2021, 10, 1657. [CrossRef]

51. Malik, M.A.; Saini, C.S. Improvement of functional properties of sunflower protein isolates near isoelectric point: Application of heat treatment. LWT 2018, 98, 411-417. [CrossRef]

52. da Silva, A.M.M.; Almeida, F.S.; Sato, A.C.K. Functional characterization of commercial plant proteins and their application on stabilization of emulsions. J. Food Eng. 2020, 292, 110277. [CrossRef]

53. Kebede, M.; Admassu, S. Application of Antioxidants in Food Processing Industry: Options to Improve the Extraction Yields and Market Value of Natural Products. Adv. Food Technol. Nutr. Sci.-Open J. 2019, 5, 38-49. [CrossRef]

54. Zhou, K.; Yu, L. Effects of extraction solvent on wheat bran antioxidant activity estimation. LWT 2004, 37, 717-721. [CrossRef]

55. Kerchev, P.; Ivanov, S. Influence of Extraction Techniques and Solvents on the Antioxidant Capacity of Plant Material. Biotechnol. Biotechnol. Equip. 2008, 22, 556-559. [CrossRef]

56. Treml, J.; Šmejkal, K. Flavonoids as Potent Scavengers of Hydroxyl Radicals. Compr. Rev. Food Sci. Food Saf. 2016, 15, 720-738. [CrossRef] [PubMed]

57. Selamoglu, Z.; Sevindik, M.; Bal, C.; Ozaltun, B.; Sen, I.; Pasdaran, A. Antioxidant, antimicrobial and DNA protection activities of phenolic content of Tricholoma virgatum (Fr.) P.Kumm. Biointerface Res. Appl. Chem. 2020, 10, 5500-5506. [CrossRef]

58. Rice-Evans, C.A.; Miller, N.J.; Paganga, G. Structure-antioxidant activity relationships of flavonoids and phenolic acids. Free Radic. Biol. Med. 1996, 20, 933-956. [CrossRef]

59. Lewoyehu, M.; Amare, M. Comparative evaluation of analytical methods for determining the antioxidant activities of honey: A review. Cogent Food Agric. 2019, 5, 1685059. [CrossRef]

60. Pereira, A.C.D.S.; Wurlitzer, N.; Dionisio, A.P.; Soares, M.V.L.; Bastos, M.D.S.R.; Alves, R.E.; Brasil, I.M. Synergistic, additive and antagonistic effects of fruit mixtures on total antioxidant capacities and bioactive compounds in tropical fruit juices. Arch. Latinoam. de Nutr. 2015, 65, 119-127.

61. Arts, M.J.T.J.; Haenen, G.R.M.M.; Wilms, L.C.; Beetstra, S.A.J.N.; Heijnen, C.G.M.; Voss, A.H.-P.; Bast, A. Interactions between Flavonoids and Proteins: Effect on the Total Antioxidant Capacity. J. Agric. Food Chem. 2002, 50, 1184-1187. [CrossRef]

62. Wang, L.; Yang, J.; Wang, Y.; Zhang, J.; Gao, Y.; Yuan, J.; Su, A.; Ju, X. Study on Antioxidant Activity and Amino Acid Analysis of Rapeseed Protein Hydrolysates. Int. J. Food Prop. 2016, 19, 1899-1911. [CrossRef]

63. Durand, E.; Beaubier, S.; Fine, F.; Villeneuve, P.; Kapel, R. High Metal Chelating Properties from Rapeseed Meal Proteins to Counteract Lipid Oxidation in Foods: Controlled Proteolysis and Characterization. Eur. J. Lipid Sci. Technol. 2021, 123, 2000380. [CrossRef]

64. Yoshie-Stark, Y.; Wada, Y.; Schott, M.; Wäsche, A. Functional and bioactive properties of rapeseed protein concentrates and sensory analysis of food application with rapeseed protein concentrates. LWT 2006, 39, 503-512. [CrossRef]

65. He, R.; Girgih, A.T.; Malomo, S.A.; Ju, X.; Aluko, R.E. Antioxidant activities of enzymatic rapeseed protein hydrolysates and the membrane ultrafiltration fractions. J. Funct. Foods 2013, 5, 219-227. [CrossRef]

66. Mäkinen, S.; Johannson, T.; Gerd, E.V.; Pihlava, J.M.; Pihlanto, A. Angiotensin I-converting enzyme inhibitory and antioxidant properties of rapeseed hydrolysates. J. Funct. Foods 2012, 4, 575-583. [CrossRef] 
67. Pan, M.; Jiang, T.S.; Pan, J.L. Antioxidant Activities of Rapeseed Protein Hydrolysates. Food Bioprocess Technol. 2009, 4, 1144-1152. [CrossRef]

68. Östbring, K.; Tullberg, C.; Burri, S.; Malmqvist, E.; Rayner, M. Protein Recovery from Rapeseed Press Cake: Varietal and Processing Condition Effects on Yield, Emulsifying Capacity and Antioxidant Activity of the Protein Rich Extract. Foods 2019, 8, 627. [CrossRef] [PubMed]

69. Djuardi, A.U.P.; Yuliana, N.D.; Ogawa, M.; Akazawa, T.; Suhartono, M.T. Emulsifying properties and antioxidant activity of soy protein isolate conjugated with tea polyphenol extracts. J. Food Sci. Technol. 2020, 57, 3591-3600. [CrossRef] [PubMed]

70. Sun, J.; Jing, H.; Mu, Y.; McClements, D.J.; Dong, S.; Xu, B. Fabrication of antioxidant emulsifiers from natural ingredients: Conjugation of egg white proteins with catechin and chlorogenic acid. Food Hydrocoll. 2020, 108, 106019. [CrossRef]

71. Quan, T.H.; Benjakul, S.; Sae-Leaw, T.; Balange, A.K.; Maqsood, S. Protein-polyphenol conjugates: Antioxidant property, functionalities and their applications. Trends Food Sci. Technol. 2019, 91, 507-517. [CrossRef]

72. Pham, L.B.; Wang, B.; Zisu, B.; Adhikari, B. Complexation between flaxseed protein isolate and phenolic compounds: Effects on interfacial, emulsifying and antioxidant properties of emulsions. Food Hydrocoll. 2019, 94, 20-29. [CrossRef] 